\title{
COMMUNITY SERVICE AT CEMARA LAUNDRY ON ENHANCING THE SME THROUGH MANAGEMENT AND INFORMATION TECHNOLOGY
}

\author{
Daris Purba \\ Universitas Putera Batam (UPB), Batam, Indonesia \\ e-mail: daris@puterabatam.ac.id \\ Evan Rosiska \\ Universitas Putera Batam (UPB), Batam, Indonesia \\ e-mail: evan.rosiska@puterabatam.ac.id \\ Nanda Harry Mardika \\ Universitas Putera Batam (UPB), Batam, Indonesia \\ e-mail: nanda.harry@puterabatam.ac.id
}

\begin{abstract}
The Covid-19 pandemic has decreased the revenue of Small and Medium Enterprises (SMEs), including the laundry business. Marketing efforts to increase revenue have also encountered obstacles, ranging from technical problems to cost constraints. This Community Service is aimed at a laundry in Cipta Asri Batam housing. The purpose of this Community Service activity is to foster laundry SMEs so that they can continue to exist by creating various marketing techniques and innovative products. The creation of superior and innovative products is expected to increase turnover. These superior products will be marketed using social media, given the government's health protocol. This service was organized by a team of lecturers and students from the Management and Information System Programs at the University of Putera Batam. The team from the management program coaches management and marketing, while the team from the information systems guides the field of using informatics systems in improving SME marketing and productivity. The involvement of students in this service activity is educational where students can learn directly from the field but also could provide guidance according to the knowledge that has been obtained. Coaching materials focus on marketing, business management, and the use of informatics systems. The activity was carried out in two meetings attended by the object of the event and the surrounding community. It is hoped that this service activity would be able to add insight for partners and be able to help empower partners in a better direction.
\end{abstract}

Keywords: SMEs, Covid 19, Management, Information Technology

\section{INTRODUCTION}

The Covid-19 virus pandemic has disrupted the people's economy (Nasution et al., 2020). Many workers were laid off, the existence of social restrictions from the government, and fear from the community resulted in a decrease in demand for 
goods/services. Facing this, the suppliers of goods/services also reduce their supplies and costs so that they can survive until things get better again.

Cemara Laundry, which opened on August 1,2020, is a micro business that emerged during a pandemic. Turnover is still small due to the insufficient customer base and the pandemic that is not over yet. Currently, Cemara Laundry still makes a small investment, which is only limited to tools and basic commodities, while the place of business is still at home.

The biggest obstacle to this increase in turnover is marketing (Hartono et al., 2012). During a pandemic like today, it is difficult to find effective and efficient marketing techniques. The technique that Cemara Laundry has tried is to use paid advertisements on Facebook as well as free advertising in housing groups on Facebook. The result is quite effective but less efficient because the costs are quite large.

Another marketing technique that is also being considered by Cemara Laundry is the ball pick-up technique using a motorized rickshaw. The constraints with this technique are the need for a large investment (Iman, 2018) to buy a motorized pedicab and the need for workers who are ready to spend their time traveling every day. The effectiveness of this ball-pick technique is still untested but it is worth trying, especially when the pandemic period is over.

To increase turnover, currently, Cemara Laundry is developing a superior package for monthly laundry services. One proven package is a package of IDR 100,000 per month with a $20 \mathrm{Kg}$ quota. This package targets young people and workers. The weakness of this package is that many customers ask for payment at the end which causes the business to lack the cash flow to move its business.

Some of the problems faced by Cemara Laundry above resulted in our team of lecturers and students from Putera Batam University interested in conducting Community Services with the title: Laundry Development in Cipta Asri Housing, Batam City to Expand Marketing and Increase Turnover. It is hoped that our coaching will make it easier for Cemara Laundry to expand its marketing and increase its turnover.

\section{METHODS}

The following are some of the community services related to SMEs survival during the Covid 19 Pandemic:

The Role of Financial Management and Digital Marketing in Efforts to Increase Sales Turnover for the Modern Intermodal Market of BSD City, South Tangerang City in the Middle of the Covid-19 Pandemic. Journal Abdi Masyarakat Humanis (Sunardi, Lesmana, et al., 2020). The methods used in this Community Service are lectures, discussions, and the provision of material on financial management and digital marketing as well as strategies that must be carried out by SMEs to survive during this pandemic, the conclusion of this Community Service in the BSD City Modern Market is that SMEs need help in terms of capital and assistance so that they can rise and be independent during this pandemic. The solution provided is capital assistance for 
SMEs by PT Sarana Jakarta Ventura with low administrative costs. This research is different because it does not specifically discuss information technology.

The Role of Digital Marketing in Efforts to Increase the Income of SMEs that Have an Impact on Community Welfare in Kab. Purwakata in the Middle of the Covid19 Pandemic. Jurnal Abdi Masyarakat Humanis (Sunardi, Sarwani, et al., 2020). The method of implementing this community service is by conducting an approach to related agencies, namely the community through workshops and socialization as well as training utilizing data collection or observation, training and workshops, and evaluation of results. The result of this dedication, namely Digital Marketing, can Increase the Income of the SMEs in the Middle of the Covid-19 Pandemic so which has an impact on increasing the welfare of the people of Kab. Purwakata in the middle of the Covid-19 Pandemic. This society service activity is different because it does not include the element of product innovation in its activities.

SME Strategy during the Covid-19 Pandemic. KANGMAS: Karya IImiah Pengabdian Masyarakat, 1 (2), 67-74 (Susanti et al., 2020). The purpose of this service is to provide knowledge on how to build a brand image of the products produced, manage finances in running their business, and manage issues that occur during a pandemic. The object is the UMKM actors. This training is carried out through the online Zoom Meeting by inviting SMEs businessmen. The results of the dedication that we have done can be concluded that collaboration between marketing, finance, and issue management needs to be considered in all conditions. It should be noted that not only the issues that occur during the pandemic period but also during normal times have been prepared so that whatever the conditions are, they can adapt well. The difference lies in that this study does not discuss information technology.

The methods used in this Community Service activity are:

1. Information / data collection and brainstorming with SMEs in Cipta Asri Housing related to their conditions during the Covid-19 pandemic by conducting interviews with UKM businessmen.

2. Providing training in management and the use of information technology by providing counseling to SMEs in Cipta Asri.

\section{RESULT AND DISCUSSION}

\subsection{Preparatory Stage}

The preparatory stage includes:

a. Initial survey. At this stage, a survey was conducted to the location of UKM in Cipta Asri Housing especially to Cemara Laundry.

b. Observation. After the survey, the objectives of the activity and the implementation time were determined.

c. Team coordination. At this stage, meetings are held regarding the division of tasks, preparation of implementation schedules, and implementation of evaluation and report preparation. 


\subsection{Implementation Stage}

The implementation stage includes:

a. Program Socialization. In the early stages of implementation, program socialization was conducted with potential partners.

b. Training / Mentoring. By the next step is to provide training / mentoring in the form of management trainers and the use of information systems to increase sales.

This community service is carried out to provide solutions to SMEs so that they can survive during the Covid-19 outbreak. More than that, this dedication is expected to make MSMEs more advanced and bigger. This service is one of the higher education tri dharma activities where the devotees provide the knowledge that is in college for the community.

The material presented to the activity participants was centered on marketing and information technology problems. To survive, SMEs must continue to carry out marketing activities assisted by information technology. Marketing difficulties due to the Pandemic can be overcome by increasing posting and advertising on social media. For posts that are not paid must be done as often as possible at least once a day. For those who pay, they can budget IDR 100,000 per month.

An experiment using paid advertising on Facebook was that laundry managed to get 4 regular customers, of which these customers had succeeded in returning the advertising cost of Rp. 100,000. However, in the second experiment with a different ad format, the ads on Facebook did not bring in any customers. By looking at this, the laundry party must be better at creating ad content and running various patterns to find an ad format that is effective and attracts customers.

Effective marketing techniques will only be found if various existing marketing patterns have been tested. Reducing prices is the easiest thing to do but it will reduce operating profits. So far what has been done is a subscription package technique that targets young people who live in boarding houses. This method has proven to be more effective in increasing the number of customers which ensures cash flow to the business.

The superior laundry product is the finished 2-hour express laundry. This product has not been tested because the equipment and labor are not ready. This product is targeted at hotel residents who need speed in washing clothes. The development of this product was ultimately postponed considering that tourist visits to Batam had decreased due to the pandemic. Currently what is being done is to prepare the equipment and manpower to be able to launch this product as quickly as possible.

\subsection{Evaluation Stage}

The evaluation stage is an assessment after a series of activities are carried out by the executor according to a predetermined schedule. This evaluation is in the form of improvements or suggestions for better activity implementation. Evaluation is also carried out on the performance of UKM after service activities are carried out to see the effectiveness of the service activities that have been carried out. 


\section{CONCLUSION}

The Community Service resulted in the following conclusions:

1. The community has not carried out effective and efficient marketing.

2. The community already knows information technology but is still unable to use it to help business activities.

3. Communities can work together with coaches and trainers but are constrained by resources and time.

4. Coaching has succeeded in providing an understanding to the community of the importance of marketing activities and the use of information technology to improve business.

\section{RECOMMENDATIONS}

This Community Service provides following recommendations:

1. The community should support local products and services.

2. The stakeholders should create better environment for the SME's.

3. The next community activity should be focusing more on creating and following standard operational procedures.

\section{ACKNOWLEDGMENTS}

Our team would like to acknowledge the support and assistance we received from the following parties:

1. UPB University for facilitating this Community Service.

2. Cemara Laundry for providing space and time to run this activity.

3. PUAN Journal managers and staff for publishing this article.

\section{REFERENCES}

Hartono, H., Hutomo, K., \& Mayangsari, M. (2012). Pengaruh Strategi Pemasaran Terhadap Peningkatan Penjualan Pada Perusahaan Dengan Menetapkan Alumni Dan Mahasiswa Universitas Bina Nusantara Sebagai Objek Penelitian. Binus Business Review, 3(2), 882. https://doi.org/10.21512/bbr.v3i2.1271

Iman, T. F. (2018). Strategi Pemasaran Jemput Bola Produk Simpanan Ummat Pada KSPPS BMT MARHAMAH Wonosobo. UIN Walisongo Semarang.

Nasution, D. A. D., Erlina, E., \& Muda, I. (2020). Dampak Pandemi COVID-19 terhadap Perekonomian Indonesia. Jurnal Benefita, 5(2), 212. https://doi.org/10.22216/jbe.v5i2.5313

Sunardi, N., Lesmana, R., Rudi, Kartono, \& Hasbiyah, W. (2020). Peran Manajemen Keuangan dan Digital Marketing dalam Upaya Peningkatan Omset Penjualan bagi Umkm Pasar Modern Intermoda Bsd City Kota Tangerang Selatan di Tengah Pandemi Covid-19. Abdi Masyarakat, 2(1), 75-86. 
http://www.openjournal.unpam.ac.id/index.php/JAMH/article/view/7416/4901

Sunardi, N., Sarwani, AM, E. N., Pranoto, \& Hasmanto, R. B. (2020). Peran Digital Marketing dalam Upaya Meningkatkan Pendapatan UKM yang Berdampak pada Kesejahtraan Masyarakat di Kab. Purwakata di Tengah Pandemi Covid-19. Abdi Masyarakat Humanis, 1(2), http://www.openjournal.unpam.ac.id/index.php/JAMH/article/view/4991

Susanti, A., Istiyanto, B., \& Jalari, M. (2020). Strategi UKM pada Masa Pandemi Covid19. KANGMAS: Karya IImiah Pengabdian Masyarakat, 1(2), 67-74. https://doi.org/10.37010/kangmas.v1i2.50 